\title{
Trends in Earnings Management and \\ Informativeness of Earnings Announcements in the Pre- and Post-Sarbanes Oxley Periods ${ }^{*}$
}

\author{
Daniel A. Cohen \\ Leventhal School of Accounting \\ Marshall School of Business \\ University of Southern California \\ Los Angeles, CA 90089 \\ Aiyesha Dey \\ Thomas Z. Lys ${ }^{* *}$ \\ Kellogg School of Management \\ Northwestern University \\ Evanston, Illinois 60208
}

February, 2005

\footnotetext{
*A previous version of this paper was titled "The Effect of the Sarbanes Oxley Act on Earnings Management: What has Changed?” We acknowledge helpful comments from Krishna Kumar, Eddie Riedl, Ira Weiss, Jerry Zimmermann, participants at the HBS Accounting and Control seminar, and participants at the 2004 LBS Accounting Symposium. All remaining errors are our own.

${ }^{* *}$ Corresponding Author (847) 491-2673, tlys@northwestern.edu
} 


\title{
Trends in Earnings Management and Informativeness of Earnings Announcements in the Pre- and Post-Sarbanes Oxley Periods
}

\begin{abstract}
We document that firms' management of accounting earnings increased steadily from 1987 until the passage of the Sarbanes Oxley Act (SOX), with a significant increase during the period prior to SOX, followed by a significant decline after passage of SOX. However, the increase in earnings management preceding SOX was primarily in poorly performing industries. We also show that the informativeness of earnings increased steadily over time, and there was no significant change in earnings informativeness following the passage of SOX. Further, we find that earnings management increased the absolute informativeness of earnings, but reduced the informativeness for a given earnings surprise, as well as reduced the abnormal return for a given amount of earnings surprise. Finally, the evidence supports the hypothesis that the opportunistic behavior of managers, primarily related to the fraction of compensation derived from options, was significantly associated with earnings management in the period preceding SOX.
\end{abstract}




\section{Introduction}

The recent wave of corporate governance failures has raised concerns about the integrity of the information provided to investors, resulting in a drop in investor confidence (Jain, Kim and Rezaee, 2003; Rezaee and Jain, 2003; Rezaee, 2002). These highly publicized failures culminated in the passage of the Sarbanes Oxley Act (SOX) on July 30, 2002. ${ }^{1}$ Upon signing SOX, President George W. Bush stated that this Act constitutes "the most far-reaching reforms of American business practices since the time of Franklin D. Roosevelt.”" The head of the AICPA commented that SOX "contains some of the most far-reaching changes that Congress has ever introduced to the business world.”3 However, although SOX proposes sweeping changes, the implications of the law and subsequent regulatory changes are yet to be ascertained.

We focus on two research questions. First, we investigate the trends in and potential determinants of corporate earnings management activities in the periods preceding and following the passage of SOX. Specifically, we analyze whether managerial opportunism or events exogenous to the firms (such as changes in economic conditions) contributed to changes in earnings management. Second, we investigate investors' reactions to earnings announcements before and after the passage of SOX. Specifically, earnings management is likely to be informative in its own right (Watts and Zimmerman, 1986). However, earnings management, particularly if it results from agency conflicts between shareholders and management, is likely to make it more difficult to infer the

\footnotetext{
${ }^{1}$ On May 6 ${ }^{\text {th }}$, 2003 at a governance conference at the Kellogg School of Management, Senator Davenport stated "Congress had to act."

${ }^{2}$ Elizabeth Bumiller, "Bush Signs Bill aimed at Fraud in Corporations,” N.Y. Times, July 31, 2002.

3 Barry C. Melancon, “A New Accounting Culture,” www.aicpa.org, September 4, 2002.
} 
actual level of corporate performance. As a result, earnings management is likely to affect the relation between earnings and stock price changes.

We begin by examining earnings management over time. The purpose of this analysis is to investigate whether the events leading to the passage of SOX were indeed characterized by a wide-spread increase in earnings management, as opposed to a few highly publicized events. We conduct our analysis by dividing the sample period into two periods: the period prior to the passage of SOX (the pre-SOX period: Q1, 1987 through Q2, 2002), and the period after the passage of SOX (the post-SOX period: Q3, 2002 through Q4, 2003). We further subdivide the pre-SOX period into two sub-periods using the "Corporate Scandal Sheet” developed by Forbes (Forbes 2002): the period prior to the major corporate scandals (the pre-SCA period: Q1, 1987 through Q2, 2001) and the period during which the major scandals occurred (the SCA period: Q3, 2001 through Q2, 2002). ${ }^{4}$ We document that the pre-SOX period was characterized by rapidly increasing earnings management that reached a peak during the SCA period. Thus, our evidence indicates that the problem was much more endemic, and not due to "a few bad apples." However, our analysis indicates that this increase is concentrated in poorly performing industries. Thus, either poorly performing firms are more likely to resort to earnings management, or currently available techniques are unable to adequately control for earnings management that is due to changing economic conditions (Dechow, Kothari, and Watts, 1998; Kothari, Leone, and Wasley, 2004). Following the passage of SOX earnings management reversed abruptly, and this result is robust with respect to industry performance.

\footnotetext{
${ }^{4}$ Such subdivision may induce hindsight bias into the analysis. However, a preliminary analysis shows that the data exhibit significant time trends (non-stationarity), and we feel that such partitioning of the sample period enables a more meaningful interpretation of the results.
} 
We then investigate one determinant of earnings management activities, labeling this hypothesis as the "opportunistic behavior hypothesis" (OBH). This hypothesis maintains that high earnings management activity during the pre-SOX period was driven by managers' opportunistic behaviors. Specifically, we examine whether the incentives derived from bonus and option compensation were related to the level of earnings management during this period.

Our evidence is partially consistent with the $\mathrm{OBH}$ as a motivation for high earnings management. In particular, we find that the fraction of compensation derived from options was significantly associated with the level of earnings management in the preSOX period, even after controlling for general economic conditions. However, we do not find an association between the fraction of compensation derived from bonus contracts and earnings management. We interpret our result as suggesting that the scandals did not represent isolated cases of corporate frauds, but rather represented an increase in the degree of accounting management in the SCA period. Moreover, although the finding of a decline in opportunistic behavior in the period following the passage of SOX does provide evidence of an impact of this Act, we cannot attribute this decline solely to SOX due to a number of concurrent events in the post-SOX period. For example, the most egregious behaviors resulted in highly publicized enforcement actions, and such actions are likely to have had a damping effect on opportunistic behavior.

Next, we investigate the trends in earnings informativeness and how earnings management affects the informativeness of earnings in the pre-SCA, SCA and post-SOX periods. We use two measures of informativeness: the volatility of security returns in the three-day window centered on earnings announcement dates - a non directional measure 
(Beaver, 1968) - and the association between earnings surprises and stock price changes - a directional measure (Ball and Brown, 1968). Our evidence indicates that the volatility of stock returns around earnings announcements is positively associated with earnings management - that is earnings management is informative (Watts and Zimmerman, 1986). However, earnings management reduces the association between earnings surprises and both the variance and the mean stock returns around earnings announcements. Jointly, our results are consistent with the notion that earnings management is informative but lowers the 'quality of earnings.' Finally, after controlling for earnings management, we do not find evidence suggesting an increase in the informativeness of earnings in the post-SOX period.

The remainder of the paper proceeds as follows. Section 2 provides a discussion of the institutional background on the major corporate scandals that took place in 2001-2002 and the passage of SOX. Section 3 develops the hypothesis and presents an overview of the related literature. Section 4 discusses the various measures of earnings management and earnings informativeness used in the study. Data and the research methods are described in Section 5, followed by a discussion of the results in Section 6. Section 7 discusses some robustness checks and Section 8 concludes.

\section{Institutional Background}

A string of major accounting scandals began with the unraveling of Enron Corporation in late 2001. Enron's activities over the preceding four years included the failure to make proper disclosures concerning various related-party transactions and to account for off-balance-sheet transactions. A number of criminal and civil investigations 
followed, along with the company's bankruptcy filing. The various governance failures that followed Enron involved distinctly different types of misbehaviors, ranging from the widely publicized case of Global Crossing's dubious financial reporting to that of Adelphia Communications Corp., and Tyco International Limited's sweetheart loans to executives. ${ }^{5}$ Figure 1 provides a timeline of the major accounting scandals that occurred in 2001-2002. The dates of these scandals were obtained from Forbes' "Corporate Scandal Sheet” (Forbes, 2002) and verified by checking the Dow Jones News Retrieval Services. These multi-billion dollar governance failures created losses for millions of ordinary investors and raised questions about the reliability of financial reporting.

One consequence of these events was the passage of SOX in 2002, the result of Congressional hearings conducted since the first admissions of fraudulent behavior made by Enron. President Bush signed SOX, also known as the Public Company Accounting Reform and Investor Protection Act of 2002, into law on July 30, 2002. SOX introduces new provisions for management, directors, auditors and analysts, and significantly raises criminal penalties for securities fraud, for destroying, altering or fabricating records in federal investigations or any scheme or attempt to defraud shareholders.

\section{Hypotheses Development and Literature Review}

\subsection{Research Questions and Hypotheses Development}

We investigate changes in firms' earnings management activities and investors' reactions to those activities with reference to Congress's and regulators' responses to the recent corporate scandals. In particular, we investigate whether the level of earnings

${ }^{5}$ Other stories of accounting improprieties included companies such as WorldCom Inc., Qwest Communications International Inc., AOL Time Warner, Rite Aid Corp., Xerox Corp., and ImClone Systems Inc. 
management changed over the sample period and potential reasons for those changes. Next, we analyze the changes in the informativeness of earnings over the sample period, and the impact of earnings management on the informativeness of earnings, relying on the evidence in Watts and Zimmerman (1986) and Guay, Kothari, and Watts (1996) that earnings manipulation per se is informative.

We focus on one theory to explain earnings management behavior of firms, and its effect on the informativeness of earnings: the "opportunistic behavior hypothesis" $(\mathrm{OBH}) . \mathrm{OBH}$ predicts that managers' choices of accounting practices are influenced by their impact on compensation.

OBH has four empirical predictions. First, changes in reported earnings are affected by changes in the compensation and incentives of managers. ${ }^{6}$ Second, even after controlling for managerial incentives, OBH predicts that earnings management would decline after the passage of SOX, either because of the sanctions imposed on managers by the Act or because of the adverse publicity and legal costs imposed on executives and firms who were accused of fraudulent reporting practices. ${ }^{7}$ Third, earnings management is informative when managers possess inside information and have incentives to mange earnings (e.g., because of compensation contracts). Therefore we expect an association between our proxy for earnings management and stock return volatility. Finally, the association between stock returns and earnings surprises depends on investors' perceptions on whether earnings management is motivated by managers' attempts to

\footnotetext{
${ }^{6}$ For the purpose of this discussion, we consider those changes as exogenous. Of course, tests of OBH become difficult, if changes in the compensation packages are the result of changes in economic activities or outlooks. We address this issue by investigating the impact of compensation after controlling for economic conditions.

${ }^{7}$ As indicated in the introduction, it is difficult to attribute the change in earnings management to SOX versus other concurrent events. For instance, the period following the scandals is likely to be marked by greater investor alertness and increased scrutiny by auditors and regulators, reducing firms' propensity to manage earnings.
} 
communicate inside information or by managers' opportunistic behavior. In the former (latter) case, higher earnings management will result in a given earnings surprise resulting in a larger (smaller) change in security prices. In other words, the level of earnings management affects the precision that investors attribute to a given earnings signal. In turn, the higher the precision of the earnings signal, the higher the earnings response (e.g., measurement errors bias regression coefficients towards zero). Thus, there exists a link between earnings management and investors responses to earnings signals.

\subsection{Related Studies}

Research documenting the trend in earnings management over time indicates that the tendency to manage earnings has increased over time (Brown, 2001; Bartov et. al., 2002; Lopez and Rees, 2001). This literature also provides evidence that managerial propensity to avoid negative earnings surprises has increased significantly over time (Brown, 2001; Bartov et. al, 2002; Matsumoto, 2002), although no significant increase has been observed in the tendency to avoid losses or earnings decreases (Burgstahler and Eames, 2003).

Brown and Caylor (2003) conduct a temporal analyses of the propensities of managers to achieve three earnings management thresholds and their valuation consequences using quarterly data from 1985-2001. They find that early in their study period (1985-1993), managers tried to avoid losses and earnings decreases more than to avoid negative earnings surprises. However, in the subsequent time period (1994-2001) they find that managers exhibited a greater inclination to avoid negative earnings 
surprises than to avoid losses, and in the last six years of the study (1996-2001) managers preferred to avoid negative earnings surprises than earnings decreases. They conclude that managers took their cues from capital markets, making negative earnings surprise avoidance their most preferred threshold in recent years, proposing that increased media coverage may be responsible for this shift.

In this paper we provide further evidence on the trend in earnings management activities of firms, with specific focus on the level of earnings management surrounding the period of heightened corporate misconduct, beginning in late 2001. We also examine the change in earnings management activity after the passage of SOX.

Studies on the informativeness of earnings have typically focused on the relation between earnings informativeness and various institutional and governance features of companies. Yeo, Tan, Ho and Chen (2002) document a relation between informativeness and managerial ownership, as well as between informativeness and external blockholdings. Gul and Wah (2002) focus on the market reaction to accounting earnings conditioned on two important corporate governance variables: insider entrenchment (high insider share ownership) and board leadership structure in terms of CEO duality (no separation between CEO and board chairman). They find that at a very high level of insider shareholding (entrenched insiders), is associated with a lower informativeness. Other studies provide evidence demonstrating an association between earnings informativeness and the levels of stock compensation (Behn, Nagy and Riley, 2002), the probability of termination of an entity (Subramanyam and Wild, 1996), and the cost of equity and trading in the stock of a country (Bhattacharya, Daouk and Welker, 2002). We contribute to this literature by documenting the trends in and potential determinants 
of earnings informativeness over time, with particular reference to the corporate scandals and the passage of SOX.

SOX generated considerable interest in the academic community. Jain, Kim and Rezaee (2003) show wider bid-ask spreads, lower depths, and higher adverse selection component of spreads in the period surrounding the corporate scandals: findings that support their hypothesis of loss in investor confidence in the financial reporting process. They also find evidence consistent with an increase in investor confidence after the passage of SOX.

Jain and Rezaee (2003) document positive abnormal returns around dates corresponding to the passage of SOX, suggesting that the market reacted positively to the passage of the Act and possible implementation effects of its provisions. They also report that firms with bigger balance sheet sizes, higher price-earnings ratios, and higher earnings retention ratios were affected more by the Act compared to other firms.

Bhattacharya, Groznik and Haslem (2002) find no evidence that the CEO and CFO certification requirements were significantly priced by investors. In a recent study Li, Pincus and Rego (2003) find no differences in stock returns between firms that manage earnings extensively and firms which manage earnings to a lesser degree, and between firms with effective versus ineffective audit committees, for individual SOX event dates.

Lobo and Zhou (2005) investigate whether the Sarbanes-Oxley Act and the resulting requirement by the SEC that financial statements be certified by firms' CEOs and CFOs resulted in an increase in the conservatism in financial reporting. They document less income-increasing earnings management in the year of certification by their CEO/CFOs than in the immediately preceding year, and faster incorporation of losses than gains in 
income in the certification year than in the year preceding certification. They interpret this as suggesting that the Sarbanes-Oxley Act and the resultant SEC requirement that CEO/CFOs certify their financial statements enhanced the quality of reported earnings by making them more conservative. In summary, studies on the effects of SOX have produced inconsistent results, possibly due to the limited time period available subsequent to SOX.

\section{Empirical Constructs}

In this section we describe the proxies used to measure earnings management and the informativeness of earnings. Section 4.1 describes our proxies for earnings management while section 4.2 discusses two informativeness measures, namely an absolute informativeness, and a directional measure to analyze the change in the informativeness of earnings.

\subsection{Earnings Management}

Based on prior research, we rely on earnings management measures commonly used in the literature, including (i) three measures of discretionary accruals, (ii) the ratio of the absolute value of accruals to the absolute value of cash flows from operation, (iii) the ratio of the change in accounts receivables to the change in sales, (iv) the ratio of the change in inventory to the change in sales, and (v) the frequency of special items reported for the period. ${ }^{8}$ While these proxies for earnings management are widely used in the

\footnotetext{
${ }^{8}$ Since we are relying on a pooled cross-sectional time series analysis, we require one observation per company quarter. Therefore, we do not use two additional metrics which have been commonly used in prior research: the ratio of the standard deviation of operating income to standard deviation of cash flows (Leuz, Nanda and Wysocki, 2001; Bhattacharya, Daouk and Welker, 2001; Zarowin, 2002), nor the
} 
literature (Jones, 1991; Kasznik, 1999; DeFond and Jiambalvo, 1994; Subramanyam, 1996; and Elliott and Hanna, 1996), each has some limitations, that is, each proxy is an imperfect measure of earnings management. To reduce the measurement error contained in any single measure, we compute the common element contained in all of them using principle factor analysis. The individual components of our earnings management proxy are discussed next.

\subsubsection{Discretionary Accruals}

One of the most common metrics used in the literature to detect earnings management is the magnitude of discretionary accruals, which proxies for the discretion used by managers to achieve their financial reporting goals. The standard model used by prior research in attempting to identify discretionary (or "unexpected") accruals is based on Jones (1991). Total accruals are regressed on variables, which are expected to vary with nondiscretionary accruals, and the unexplained portion (i.e., the residuals) is interpreted as discretionary accruals. These models have been used either in a time-series firmspecific framework, or they have been estimated in the cross-section for each industry (e.g., Subramanyam, 1996). We use a cross-sectional model of discretionary accruals, where for each quarter we estimate the model for every industry classified by its 2-digit SIC code. Thus, our approach controls for industry-wide changes in economic conditions that affect total accruals while allowing the coefficients to vary across time (Kasznik, 1999; DeFond and Jiambalvo, 1994). ${ }^{9}$

contemporaneous correlation between changes in accounting accruals and changes in operating cash flows (Myers and Skinner, 1999; Leuz, Nanda and Wysocki, 2001; Zarowin, 2002).

${ }^{9}$ We obtain qualitatively the same results when we use a time-series approach which assumes temporal stationarity of the parameters for each firm. 
Our first model is the modified cross-sectional Jones model discussed in DeFond and Subramanyam (1998). This model assumes that the change in revenues less the change in accounts receivable is free from managerial discretion (i.e., credit sales are assumed to be discretionary). The modified Jones model is estimated for each 2-digit SIC-quarter grouping as follows:

$$
\frac{T A_{j q}}{\text { Asset }_{j q-1}}=\alpha_{0} \frac{1}{\text { Asset }_{j q-1}}+\beta_{1} \frac{\left(\Delta \text { Sales }_{j q}-\Delta A R_{j q}\right)}{\text { Asset }_{j q-1}}+\beta_{2} \frac{P P E_{j q}}{\text { Asset }_{j q-1}}+\varepsilon_{j q}
$$

where for firm $j$ and quarter $q, T A_{j q}$ is the total accruals, defined as earnings minus cash flow; $A_{j q}$ represents total assets; $\Delta$ Sales $_{j q}$ is the change in sales; $\triangle A R_{j q}$ is the change in accounts receivables; and $P P E_{j q}$ represents gross property, plant, and equipment. ${ }^{10}$ We use current cash flows from operations, excluding extraordinary items and discontinued operations $(\mathrm{CFO})$, to calculate accruals.

Industry-quarter specific parameters obtained from equation (1) are used to estimate firm-quarter specific nondiscretionary accruals $(N D A)$ as a percent of lagged total assets:

$$
N D A_{j q}=\hat{\alpha}_{0} \frac{1}{\text { Asset }_{j q-1}}+\hat{\beta}_{1} \frac{\left(\Delta \text { Sales }_{j q}-\Delta A R_{j q}\right)}{\text { Asset }_{j q-1}}+\hat{\beta}_{2} \frac{P P E_{j q}}{\text { Asset }_{j q-1}}
$$

Our first measure of discretionary accruals $D A_{1}$ is the difference between $T A_{j q} / A_{s s e t s_{j q-1}}$ and $N D A_{j q}$. We use the absolute value of $D A_{l}$ as a measure of discretionary accruals.

A major criticism of discretionary accruals models is that they can classify nondiscretionary accruals as discretionary. To mitigate this concern, we use two additional models to estimate discretionary accruals (Dechow et al., 2003; McNichols, 2000; Larcker and Richardson, 2003) as well other metrics measuring earnings management (see below). Previous research has shown that measures of unexpected

${ }^{10}$ Throughout the paper we depict variables through italics, while constructs are not italicized. For example, ROA is an acronym for return on assets, but $R O A$ represents the variable return on assets. 
accruals are more likely to be misspecified for firms with extreme levels of performance (Dechow et al., 1995; Kasznik, 1999). In particular, Dechow et al. (1995) and Kasznik (1999) document that estimated discretionary accruals are negative for firms with low earnings and positive for firms with high earnings. To address this issue, we use the modified Jones model specified in equation (1), where we include a measure of current operating performance, the current cash flows from operations excluding extraordinary items, as a control variable:

$$
\frac{T A_{j q}}{\text { Asset }_{j q-1}}=\alpha_{0} \frac{1}{\text { Asset }_{j q-1}}+\beta_{1} \frac{\left(\Delta \text { Sales }_{j q}-\Delta A R_{j q}\right)}{\text { Asset }_{j q-1}}+\beta_{2} \frac{P P E_{j q}}{\text { Asset }_{j q-1}}+\beta_{3} \frac{C F O_{j q}}{\text { Asset }_{j q-1}}+\varepsilon_{j q}
$$

The third model relies on the discussion in McNichols (2000), Dechow et al. (2003) and Larcker and Richardson (2003). Since accruals are changes in working capital accounts, one would expect fast growing firms to have larger accruals (McNichols 2000, 2002). In line with this prediction, we include the book-to-market ratio $(B M)$ as a proxy for expected growth in firm's operations. ${ }^{11} B M$ is measured as the ratio of the book value of common equity to the market value of common equity:

$$
\frac{T A_{j q}}{\text { Asset }_{j q-1}}=\alpha_{0} \frac{1}{\text { Asset }_{j q-1}}+\beta_{1} \frac{\left(\Delta \text { Sales }_{j q}-\Delta A R_{j q}\right)}{\text { Asset }_{j q-1}}+\beta_{2} \frac{P P E_{j q}}{\text { Asset }_{j q-1}}+\beta_{3} \frac{C F O_{j q}}{\text { Asset }_{j q-1}}+\beta_{4} B M_{j q}+\varepsilon_{j q}
$$

The industry-quarter-specific parameters obtained from equations (3) and (4), respectively, are used to estimate firm-quarter-specific nondiscretionary accruals as a percent of lagged total assets, as in the first model specified in equation (1). Our second and third measures of discretionary accruals are $D A_{2}$ and $D A_{3}$, where each of the estimates is the difference between $T A_{j q} /$ Assets $_{j q-1}$ and the predicted value based on the estimated parameters (i.e., the residual value).

\footnotetext{
${ }^{11}$ Dechow et al. (2003) show that such an advanced model has a greater explanatory power than the crosssectional modified Jones model.
} 


\subsubsection{Additional Metrics of Earnings Management}

We use the ratio of the absolute value of total accruals to the absolute value of cash flow from operations $(|T A| /|C F O|)$, the ratio of the change in accounts receivable to the change in sales ( $\triangle A R / \triangle S A L E S)$, and the ratio of the change in inventories to the change in sales ( $\triangle I N V / \triangle S A L E S)$ as three additional measures of earnings management. We include the latter two measures to capture incidences of "channel stuffing," another common method firms use to manage earnings.

Managers may also use individual accounts to reach earnings targets. We take this possibility into account and compute an additional earnings management metric using the value of special items reported for the period. We compute this metric using the value of special items for the period scaled by the total assets at the beginning of the period. Following Elliott and Hanna (1996), we define a negative write-off as a negative special item exceeding $1 \%$ of the beginning of the quarter total assets. For each firm-quarter we compute the frequency of negative special items (Negative Write-offs) and use this as another measure of earnings management. Using the individual variables discussed in section 4.1.1 and 4.1.2, we construct an over-all index, discussed next.

\subsubsection{Earnings Management Score}

Although the above earnings management metrics are commonly used in the accounting literature, earnings management by its very nature is not observable, and there exists no consensus regarding the "best” measure of earnings management. The literature provides several concerns about using each measure as a proxy for earnings management. One important criticism is that firms may employ several tools to manage earnings, and 
focusing on a single measure may not be the right approach. To address this issue we perform principal factor analysis to construct an index of earnings management for each firm-quarter, by aggregating the common information across the different measures. This approach is likely to capture the overall level of earnings management in a firm more effectively than any of the single measures. ${ }^{12}$ We refer to this overall measure of earnings management as $E M_{-} S C O R E_{j q}$.

\subsection{Informativeness Metrics}

We use two measures of the informativeness of earnings disclosures. The first metric $\left(A N N V A R_{j q}\right)$, measures the abnormal return variance in the three-day quarterly earnings announcement window for each firm $j$ and quarter $q$ (Beaver, 1968). Abnormal return for a firm $j$ on day $t\left(A R_{j, t}\right)$ is defined as the return of firm $j$ minus the value-weighted market return on day $t$. We compute $A N N V A R_{j q}$ as:

$$
A N N V A R_{j q}=\sum_{t \in A_{j}}\left[A R_{j, t \in A_{j}}-\overline{A R}_{j, t \in A_{j}}\right]^{2}
$$

where for firm $j$ and quarter $q, A_{j}$ represents the three-day announcement period centered on the announcement date of quarter $q$, and $\overline{A R}_{j, t \in A_{j}}$ represents the average abnormal return for the three-day announcement period. Notice that $A N N V A R_{j q}$ is a non-directional measure of absolute information content in the sense that quarters with a large information flow are likely to have large announcement period return variances.

\footnotetext{
${ }^{12}$ We acknowledge that the factor analysis procedure may be capturing the common measurement error across the various individual variables. However, if that were true then we should not observe any significant associations in any of our tests. Moreover, we perform two robustness checks (see Section 7 for a description of these tests) which confirm that this metric is not merely an aggregation of measurement errors.
} 
To investigate the interaction between earnings management and earnings surprises we use the sum of the announcement period abnormal returns as a second metric $\left(\operatorname{ANNRET}_{j q}\right)$

$$
\operatorname{ANNRET}_{j q}=\sum_{t \in A_{j}} A R_{j, t \in A_{j}}
$$

We use $A N N R E T_{j q}$ to study the direction of the market response to earnings announcements.

\section{Data and Research Method}

\subsection{Data Selection and Sample Description}

The sample is obtained from the COMPUSTAT quarterly industrial and research files and CRSP daily files for the period 1987-2003. We restrict our sample to all nonfinancial firms with available data, and require at least 8 observations in each 2-digit SIC-quarter grouping. We require that each firm-quarter observation has the data necessary to calculate the three discretionary accruals metrics. This restriction likely introduces a survivorship bias into the sample resulting in larger and more successful firms. We expect that this will reduce the variation in our earnings management metrics thus making it a conservative test of our research questions.

Following Collins and Hribar (2002), we use cash flows from operations obtained from the Statement of Cash Flows reported under the Statement of Financial Accounting Standards No. 95 (SFAS No. 95, FASB 1987). ${ }^{13} \quad$ The sample period of 1987-2003 permits us to use SFAS No. 95 statement of cash flow data to estimate accruals, rather

\footnotetext{
${ }^{13}$ SFAS No. 95 requires firms to present a statement of cash flows for fiscal years ending after July 15, 1988. Some firms early-adopted SFAS No. 95, so our sample begins in 1987.
} 
than a balance sheet approach. Stock return data is obtained from CRSP. At present, COMPUSTAT data are available through Q4, 2003, while the CRSP daily stock return file extends through December 31, 2002. Our analysis of earnings management relies on data through Q4, 2003, and the analysis of the informativeness of earnings only uses sample points corresponding to the intersection of the observations from COMPUSTAT and CRSP.

The sample obtained from COMPUSTAT consists of 10,504 firms representing 185,196 firm-quarter observations. Merging this sample with the CRSP daily file results in a sample of 5,538 firms representing 80,963 firm-quarter observations (the full sample). To test our hypothesis, we use managerial compensation and incentives data from ExecuComp, which is available only from 1992 onwards. Thus, merging the full sample with ExecuComp limits the sample period to 1992 through 2003, reducing the sample to 2,078 firms and 33,581 firm-quarter observations (the ExecuComp sample).

\subsection{Research Method}

\subsubsection{Event Periods}

In our analysis we focus on earnings management and the informativeness of accounting disclosures across two main time periods - the pre-SOX period (further classified into the pre-SCA and the SCA periods), and the post-SOX period. The classification into the different time periods analyzed in this study is based on the period of the major corporate scandals (based on Forbes' "Corporate Scandal Sheet," Forbes 2002) and the passage of SOX. The pre-SOX period extends from Q1, 1987 through Q2, 2002, and the post-SOX period extends from Q3, 2002 through Q4, 2003. Within the 
pre-SOX period, we classify the period from Q1, 1987 through Q2, 2001 as the pre-SCA period, and the period from Q3, 2001 through Q2, 2002 as the SCA period. Figure 2 depicts these different time periods analyzed.

Table 1A provides summary statistics of the full sample while Table $1 \mathrm{~B}$ provides summary statistics of the ExecuComp sample. ${ }^{14}$ As indicated in the tables, both samples are dominated by large firms. More importantly, requiring the availability of CRSP and ExecuComp data while considerably increasing firm size, does not seem to have a significant impact on fundamental measures such as leverage, growth of sales, or market to book ratios.

\subsubsection{Determinants of Earnings Management and Earnings Informativeness}

We begin our analysis by testing the trends in and determinants of the level of earnings management over time by estimating the following regression:

$$
\begin{aligned}
& \text { EM_SCORE }_{j q}=\alpha_{0}+\alpha_{1} \times Q 1+\alpha_{2} \times Q 2+\alpha_{3} \times Q 3+\alpha_{4} \times \text { Time }+\alpha_{5} \times Q 1 \times \text { Time } \\
& +\alpha_{6} \times Q 2 \times \text { Time }+\alpha_{7} \times Q 3 \times \text { Time }+\alpha_{8} \times S C A+\alpha_{9} \times S O X+\alpha_{10} \times B I G_{j q}+\alpha_{11} \times G D P_{q} \\
& +\alpha_{12} \times I N D_{-} \text {ROA }_{j q}+\alpha_{13} \times \text { BONUS }_{j q}+\alpha_{14} \times \text { BONUS }_{j q} \times S C A_{j q}+\alpha_{15} \times \text { BONUS }_{j q} \times S O X \\
& +\alpha_{16} \times \text { OPTION } \\
& j q
\end{aligned}
$$

In the above equation, $E M_{-} S C O R E_{j q}$, is the score obtained by principal factor analysis of the six earnings management metrics (three discretionary accruals measures, ratio of the absolute value of accruals to the absolute value of cash flows from operations, ratio of the change in accounts receivables to the change in sales, ratio of the change in inventories to the change in sales and the frequency of negative special items); $Q 1, Q 2$, and $Q 3$ are quarter dummies; Time is the calendar year minus 1987; SCA is a dummy variable that is

\footnotetext{
${ }^{14}$ Whenever possible, we perform the tests on both the full and the ExecuComp samples to assess the impact of the ExecuComp selection on our results.
} 
equal to 1 for the time period Q3, 2001 through Q2, 2002, and 0 otherwise (represents the SCA period); SOX is a dummy variable that is equal to 1 for all fiscal quarters ending after Q3, 2002, and 0 otherwise (represents the post-SOX period); $B I G$ is a dummy variable equal to 1 if the auditor is a big-eight audit firm (or their successors); GDP is the percent change in the real gross domestic product from the previous quarter (a proxy of overall economic activity); and $I N D_{-} R O A_{j q}$ is the average return on assets of firm $j$ 's two-digit industry (a proxy for industry-specific economic activity), computed after excluding the return on assets of firm $j ;{ }^{15}$ BONUS is the average bonus compensation as a proportion of total compensation received by the top five executives of a firm; and OPTION represents the Black-Scholes value of option compensation as a proportion of total compensation received by the top five executives of a firm. The variables BONUS and $O P T I O N$ are included to proxy for compensation and incentives variables that may induce opportunistic behavior in managers (these test for $\mathrm{OBH}$ ).

We include the variables GDP and $I N D \_R O A$ as proxies for real economic activity. ${ }^{16}$ We include these proxies to control for the effect of economic activity on earnings management. While some of our measures of earnings management adjust for changes in real activity by construction (e.g., discretionary accruals), others do not (e.g., write-offs). As a result, what might be classified as opportunistic earnings management may in fact be a consequence of changing economic conditions, either because the metric itself has not been adjusted for real activity, or because the adjustment was not adequate. In other

\footnotetext{
${ }^{15}$ Guenther and Young (2000) provide evidence of a high association between ROA and the economic growth rate, indicating that ROA reflects real economic activity in a timely manner. We exclude the firm in calculating the average industry ROA in order to avoid any mechanical associations among the variables in the regressions.

${ }^{16}$ Ideally, we would also have liked to include operating cash flows in order to proxy for the economic environment, but including operating cash flows would induce a mechanical relation with our earnings management variable (due to the way we construct $E M \_S C O R E$ ).
} 
words, discretionary accruals, write-offs, etc. may also reflect firms' responses to and representations of changes in economic conditions. If this were true, then changes in earnings management metrics will coincide with changes in measures of economic activity such as operating cash flows, revenues, prior stock returns, industry performance, changes in gross domestic product, etc. In this case, while increases in earnings management will be associated with increases stock return volatility, this association should diminish after controlling for changes in economic activities. Further, we should observe no change in the relation between earnings surprises and stock price changes. Specifically, since earnings management is a proxy for changes in economic activities, it does not imply changes in the quality of earnings. ${ }^{17}$ As a result, we would not expect a reduction in the relation between earnings surprises and stock price changes.

We include control variables for the auditors in the above regression in order to examine whether the earnings management activity of firms audited by the large audit firms were different from the rest of the sample firms over the three sub-periods analyzed. Note that we make no claim that differences in the earnings management activities (if any) of these firms were due to the monitoring activities of the audit firms, since there could be a self-selection, where certain types of firms select big audit firms. In addition, to the extent that audit firms specialize in specific industries and levels of earnings management are likely to vary across industries, the audit firm dummies may also control for industry characteristics.

\footnotetext{
${ }^{17}$ However, as a caveat, a change of the transitory and permanent components of earnings will also change the relation between earnings surprises and stock price changes.
} 
Next, we examine the change in the informativeness of earnings over time and the relation between earnings management and earnings informativeness by estimating the following regression:

$$
\begin{aligned}
& D E P_{j q}=\alpha_{0}+\alpha_{1} \times V A R \_Q T R+\alpha_{2} \times Q 1+\alpha_{3} \times Q 2+\alpha_{4} \times Q 3+\alpha_{5} \times \text { Time } \\
& +\alpha_{6} \times Q 1 \times \text { Time }+\alpha_{7} \times Q 2 \times \text { Time }+\alpha_{8} \times Q 3 \times \text { Time }+\alpha_{9} \times S C A+\alpha_{10} \times S O X \\
& +\alpha_{11} \times S U R P R I S E_{j q}+\alpha_{12} \times G D P+\alpha_{13} \times I N D_{-} R_{1} O A+\alpha_{14} \times E E_{-} S C O R E_{j q} \\
& +\alpha_{15} \times \text { EM_SCORE }_{j q} \times S U R P R I S E_{j q}
\end{aligned}
$$

where the dependent variables are $D E P_{j q}=A N N V A R_{j q}$ and $D E P_{j q}=A N N R E T_{j q}$ respectively. In the above equation, $V A R \_Q T R$ is the variance of returns on all days in the quarter other than the three-day earnings announcement period, which controls for the variance of the information released for a firm during the entire quarter; and $S U R P R I S E_{j q}$ is the surprise in the earnings announcement for firm $j$ in quarter $q$ defined as follows. For the regression with $A N N R E T_{j q}$ as the dependent variable, $S U R P R I S E_{j q}$ is measured as the earnings per share for the quarter less the earnings per share of the corresponding quarter in the previous year, scaled by the price. For the regression with the dependent variable $A N N V A R_{j q}$, it is measured as the square of the directional surprise measure described in the preceding sentence. For the regression with $A N N R E T_{j q}$ as the dependent variable, we exclude the variable $V A R \_Q T R$ from the regression. The other variables are defined as in equation (7).

\section{Results}

Section 6.1 reports the descriptive statistics of earnings management and earnings informativeness. Then, section 6.2 discusses tests of the determinants of earnings 
management and section 6.3 presents the determinants of changes in the informativeness of earnings.

\subsection{Descriptive Statistics: Earnings Management and Earnings Informativeness}

Table 2 summarizes the eight individual components of EM_SCORE, our proxy of earnings management, $E M \_S C O R E$, and $A N N V A R$, our non-directional measure of information content. To summarize the data, we estimate two regressions. First, we regress each of the variables on a time trend and a dummy variable taking the value of 1.0 in the post-SOX period (Q3, 2002 to Q4, 2003) and zero otherwise (Table 2, Panel A). Second, we regress each of the variables on a time trend, the post-SOX period dummy variable and a dummy variable taking the value of 1.0 for the SCA period from Q3, 2001 to Q2, 2002 (Table 2, Panel B). We choose this procedure to describe the variables because many of our variables exhibit significant time trends (non-stationarity), rendering a traditional summary statistics uninformative.

The results in Panel A indicate a significant over-time increase in each of the three discretionary accrual measures and the frequency of negative write-offs and an over-time decrease in the change in the ratio of inventory changes divided by changes in sales. We detect no significant time trend in the ratio of changes in account receivable to sales and the ratio of the absolute value of total accruals to the absolute value of cash flows from operations. A positive time trend is also reflected by our aggregate earnings management proxy. Jointly these results suggest that earnings management has been increasing over the sample period. However, the dummy variable for the post-SOX period, while negative, is not statistically significant at conventional levels. Thus, this preliminary 
analysis does not indicate that the passage of the SOX Act was associated with a decline in earnings management.

We repeat this analysis in Panel B by adding a dummy variable for the SCA period. This addition does not change our conclusion regarding the time trend. However, adding the dummy variable for the SCA period indicates that the passage of SOX was associated with a reduction in earnings management and that the SCA period was generally associated with unusually high level of earnings management. Inspection of Figure 3 provides insight as to why the addition of the SCA dummy variable changes the inferences obtained form the SOX dummy variable: The figure indicates that the SCA period was indeed associated with a high level of earnings management. As a result, not controlling for this effect (Panel A) results in a lower intercept and a higher slope which then results in a smaller reduction in earnings management in the post-SOX period.

Finally, the last row of Table 2 documents a positive time trend for the earnings informativeness measure, indicating that earnings announcements became more informative in the sample period. However, we find no difference in informativeness of earnings announcements between the pre-SOX and post-SOX periods (Panel A). We find that the SCA period was characterized by a marginally lower announcement period return variance - this result is surprising as one would typically expect earnings management to be informative (Watts and Zimmerman 1986). Figure 4 plots ANNVAR over the entire 1987-2002 time period. Interestingly, while the SCA and post-SOX periods are characterized by low announcement period return variances, the period immediately preceding the SCA period had an unusually high level of announcement period return variance. 
In summary, the above analysis indicates that the overall level of earnings management decreased from the SCA period to the post-SOX period. However, there was significantly higher earnings management during the SCA period as compared to the pre-SCA period. One interpretation of this result is that the SCA period was characterized by higher earnings management, and the scandal firms were not just a "few bad apples," but a representation of the high level of corporate misconduct. Another observation is that although earnings management increased from the pre-SCA to the SCA period, it declined significantly from the SCA period to the post-SOX period. Whether this decline is a caused by the passage of the SOX Act, or due to other concurrent events (such as the negative publicity of the most egregious governance failures) cannot be inferred from the data. Finally, the SCA period is characterized by lower (significant at the 10 percent level) informativeness. The determinants of earnings management are analyzed next.

\subsection{Determinants of Earnings Management}

Table 3 presents the determinants of the level of earnings management by firms, as proxied by the principal factor analysis score, $E M_{-} S C O R E_{j q}$. We test OBH using compensation data from ExecuComp available for the 1992-2003. The reduced sample consists of 33,595 observations. To ensure that the inferences drawn are not affected by the sample we first re-estimate regression (7) excluding the compensation variables on both the full sample (Table 3, Panel A) and the ExecuComp subsample (Table 3, Panel B). The results indicate that restricting the sample to the ExecuComp sub-set does not alter the main tenor of the results. 
However, estimating (7) using both the full sample and the ExecuComp subsample results in one unexpected outcome: we find a negative and significant coefficient for $S C A$. We are surprised by this result, especially in light of the results in Table 2 and in Figure 3, indicating that the SCA period was characterized by unusually high earnings management. Further investigation, however, indicates that this result is caused by the inclusion of $I N D \_R O A$. Once we exclude $I N D \_R O A$, the coefficient on $S C A$ becomes positive $(t=5.64)$. One implication of these results is that earnings management was particularly high during the SCA period in industries that were performing poorly. Alternatively, poor economic condition may be accompanied by more accruals, writeoffs, etc.

The results of regression (7) are reported in Table 3, Panel C. The three dummy variables $Q 1, Q 2$ and $Q 3$ are significantly negative, indicating that relative to $\mathrm{Q} 4$, there is less earnings management in the first three fiscal quarters. This result is consistent with the notion that most contracts are based on annual numbers and, as a result, there is no benefit in managing accounting numbers before knowing what the annual results will be.

Consistent with the preliminary analysis in Table 2, we find positive trends in the level of earnings management, indicating that earnings management increased over the sample period. However, the quarterly trend variables are negative, indicating that the time trend was smaller (but still positive) for Q1-Q3.

Both $S C A$ and $S O X$ are significantly negative, implying that, controlling for the other independent variables, both periods are characterized by lower earnings management. While this result coincides with our expectations for $S O X$, we are surprised that the $S C A$ is also negative. As indicated above, additional analysis shows that this result is caused 
by the inclusion of the $I N D_{-} R O A$ variable. Excluding this variable results in a positive and significant coefficient for $S C A(\mathrm{t}=2.17)$.

Several simultaneous occurrences could have contributed to a decrease in earnings management after passage of SOX, including the increased vigilance of investors, auditors and regulators, and greater care taken by managers in financial reporting after the adverse publicity caused by the scandals. ${ }^{18}$ Thus, we are cautious in attributing the decrease in the level of earnings management solely to the passage of the SOX Act.

Of greater interest are the potential explanations for the changes in the level of earnings management. For the entire period, we find that the percentage of bonus compensation is not correlated with earnings management. However, bonus is significantly positive in the SCA period and significantly negative in the post-SOX period. However, despite the similarity of those two coefficients, we can reject the hypothesis that BONUS $\times S C A=-B O N U S \times S O X(\mathrm{~F}=16.68, \mathrm{p}<0.01)$. In contrast, the percentage of compensation derived from option is significantly positively correlated with earnings management for the entire period and this effect did not increase in the SCA period. The coefficient for OPTION in the post-SOX period is significantly negative and of the same magnitude as the coefficient for the entire period; however, we can reject the hypothesis that $O P T I O N=-O P T I O N \times S O X(\mathrm{~F}=24.59, \mathrm{p}<0.01)$.

This result is reinforced by Figure 5 which plots bonus and option compensation (based on a Black Scholes valuation) as a percentage of total compensation. The figure indicates that while bonus compensation was relatively stable around 15 percent over the entire period, option compensation increased from about 30-40 percent in the 1990s to

\footnotetext{
${ }^{18}$ We thank the referee for pointing this out.
} 
almost 90 percent in 2000-2001 time period. Overall these results support OBH and identify option compensation as a primary variable that is correlated with earnings management.

The coefficients for GDP and IND_ROA, our proxies for real economic activity, are negative and significant. As indicated above, this result has two (not necessarily mutually exclusive) interpretations. First, it suggests that even absent opportunistic behavior by managers, poor economic condition are accompanied by more accruals, write-offs, etc. Second, corporations are more likely to manage earnings when conditions are poor. However, even after controlling for economic conditions, we find a significant (albeit only at the 10 percent level) reduction in management following passage of SOX. Finally, we find evidence that the earnings management by clients of big auditors is significantly less than that of firms audited by non-big audit firms. In unreported results, we did not find significant differences in earnings management between big and non-big audit firm clients between the pre-SCA, the SCA, and the post-SOX periods.

\subsection{Determinants of Earnings Informativeness}

The results for the tests on the informativeness of earnings (equation 8) are reported in Table 4. Panel A corresponds to the results obtained when the dependent variable used is the variance of abnormal returns in the three-day earnings announcement period $\left(A N N V A R_{j q}\right)$, while Panel B corresponds to the results obtained when the dependent variable used is the sum of abnormal returns in the three-day earnings announcement period $\left(A N N R E T_{j q}\right) .{ }^{19}$

\footnotetext{
${ }^{19}$ We also repeat these tests on the ExecuComp sample (not reported). The results are not materially different from those in the total sample.
} 
The results in Panel A of Table 4 indicate that $A N N V A R_{j q}$ is positively correlated with $V A R \_Q T R$, the variance of abnormal returns in the quarter (excluding the three-day announcement period). ${ }^{20}$ The evidence indicates that earnings announcements became more informative over time in absolute terms. However, we find no clear patterns across the quarters and across the quarters over time. We find that the volatility of announcement period stock returns was lower in the SCA period and marginally higher in the post-SOX period. Consistent with expectations, we find that earnings surprises are associated with larger return variances. Earnings management is associated with higher absolute informativeness of earnings announcements. However, the interaction between earnings management and earnings surprise is negative, indicating that earnings management reduces the informativeness of a given earnings surprise. Finally, the results for the proxies for economic activity are mixed: $I N D_{-} R O A$ is not significant while the coefficient of $G D P$ is negative and significant.

Panel B reports the results for ANNRET. The evidence indicates that earnings announcement abnormal returns were smaller for Q1 and Q3 than for Q4. However, the coefficients of Time $\times Q 1$ and Time $\times Q 3$ indicate that the magnitude of the abnormal returns for Q1 and Q3 have been increasing over time. We find the magnitude of earnings announcement abnormal returns did not differ across the three periods. Consistent with expectations, we find that earnings surprises are positively correlated with announcement period abnormal returns. Finally, while we find no significant

\footnotetext{
${ }^{20}$ This result may be due to one of two effects. First, the positive coefficient may indicate that firms with large return variances have large variances across announcement and non-announcement days. Second, it may indicate that there is a complimentarity in information: quarters with higher information flows have also more informative earnings announcements. To discriminate across these two explanations, we reestimate (8) on a firm-by-firm basis. The results indicate that the coefficient on VAR_QTR remains positive and significant on a firm-by-firm regression. Thus, this implies that informative earnings are accompanied by releases of complimentary information throughout the quarter.
} 
association between earnings management and earnings announcement abnormal returns, we find that higher earnings management reduces the association between surprises and abnormal returns - consistent with the notion that earnings management reduces the quality of earnings.

Generally, the above evidence supports OBH. Specifically, we find a significant association between earnings management and stock return volatility, even after we control for changes in economic activities. Moreover, we find that earnings management decreases the absolute informativeness of earnings surprises and reduces the abnormal return for a given amount of earnings surprise, consistent with earnings management reducing the quality of earnings. In fact, these results suggest that earnings management is informative but it reduces the informativeness of earnings surprises.

\section{Robustness Checks}

We perform two robustness checks in order to confirm that our earnings management metric, EM_SCORE, indeed is measuring what it is intended to measure, i.e., earnings manipulation activity by firms. We first test how the scandal firms rank in terms of the EM_SCORE. Since these firms were the most serious offenders, if the EM_SCOREs corresponding to these firms are high, then that assures that this metric we form using the factor analysis method is not simply capturing the common measurement error across the various individual variables. For each quarter we form earnings management scores for all the scandal firms (see Figure 1 for the list of scandal firms). ${ }^{21}$ Then divide all sample firms in either three or ten portfolios based on EM_SCORE and compute in which the

${ }^{21}$ This includes the scores for all the scandal firm data we have for that particular quarter. 
scandal firms would fall. For both three group ranks and decile ranks, we find that in the later periods of the sample (particularly 2000 onwards), the scandal firms have the highest ranks in most quarters.

In the second robustness test, we sort the firms by EM_SCORE and form 10 portfolios for a given quarter q. Then we compute the mean EM_SCORE for each portfolio in $\mathrm{q}+1$ and $\mathrm{q}+2$ and compute the correlation of the portfolio ranks between $\mathrm{q}+1$ and $\mathrm{q}+2$. Next we repeat this analysis by sorting on the EM_SCOREs for the next available quarter, i.e., $\mathrm{q}+1$, and construct 10 portfolios. Again, we compute the correlation of the portfolio ranks between $\mathrm{q}+2$ and $\mathrm{q}+3$, and so on. We find that the average correlation across all adjacent portfolios is approximately 0.5 and significant at the 1 percent level. This test provides additional confidence in our earnings management index, and confirms that this index is not merely an aggregation of common measurement error across the individual earnings management variables.

\section{Summary and Conclusion}

This paper investigates over-time changes in earnings management and informativeness of earnings disclosures, and whether passage of SOX affected earnings management and the informativeness of earnings. Our results indicate that earnings management increased steadily over the sample period. In addition to this trend, we find that earnings management increased dramatically during the period preceding SOX, followed by a significant decline after the passage of SOX. However, the nature of our analysis does not provide conclusive evidence whether this reversal was caused by SOX, a response to the publicity to the scandals, or other concurrent events. 
Our results indicate that the informativeness of earnings increased in absolute terms in the sample periods, but that there was no significant change in the earnings announcement window abnormal returns. Further, we find a marginally significant increase in the absolute earnings informativeness metric, but no significant change in the earnings announcement window abnormal returns following the passage of SOX. Finally, the evidence leads us conclude that the opportunistic behaviors of managers was one of the determinants of earnings management and the informativeness of earnings primarily related to dramatic increases in the fraction of compensation derived from options. 


\section{References}

Bartov, E., D. Givoly, and C. Hayn. 2002. The Rewards to Meeting or Beating Analysts' Forecasts. Journal of Accounting and Economics 33: 173-204.

Beaver, W. 1968. The Information Content of Annual Earnings Announcements. Journal of Accounting Research 6: 67-92.

Behn, B., A. Nagy, and R. Riley. 2002. The Association between Stock/Compensation Mix and Earnings Usefulness. Working Paper, University of Tennessee, John Carroll University and West Virginia University.

Bhattacharya, U., H. Daouk, and M. Welker. 2003. The World Pricing of Earnings Opacity. The Accounting Review 78: 641-678.

Bhattacharya, U., P. Groznik, and B. Haslem. 2002. Is CEO Certification of Earnings Numbers Value-Relevant? Working Paper, Indiana University.

Brown, L. D. 2001. A Temporal Analysis of Earnings Surprises: Profits versus Losses. Journal of Accounting Research 39: 221-241.

Brown, L. D., and M. L. Caylor. 2003. A Temporal Analysis of Earnings Management Thresholds. Working Paper, Georgia State University.

Burgstahler, D., and M. Eames. 2003. Earnings Management to Avoid Losses and Small Decreases: Are Analysts’ Fooled? Contemporary Accounting Research 20: 253-294.

Burgstahler, D. and I. Dichev. 1997. Earnings Management to Avoid Earnings Decreases and Losses. Journal of Accounting and Economics 24, 99-126.

Collins, D. W., S.P. Kothari, J. Shanken, and R. G. Sloan. 1994. The Lack of Timeliness and Noise as Explanations for the Low Contemporaneous Return - Earnings Association. Journal of Accounting and Economics: 289-324.

Dechow, P., Kothari, S., Watts, R. 1998. The relation between earnings and cash flows, Journal of Accounting \& Economics 25, 133-168.

Dechow, P. M., S. A. Richardson, and A. I. Tuna. 2003. Why are Earnings Kinky? An Examination of the Earnings Management Explanation. Review of Accounting Studies 8: 355-384.

Dechow, P. M., R. G. Sloan, and A. P. Sweeney. 1995. Detecting Earnings Management. The Accounting Review 70: 193-225.

DeFond, M. L., and J. Jiambalvo. 1994. Debt Covenant Effects and the Manipulation of Accruals. Journal of Accounting and Economics 17: 145-176. 
DeFond, M. and K.R. Subramanyam. 1998. Auditor Changes and Discretionary Accruals. Journal of Accounting and Economics 25: 35-67.

Dichev, I., and D. J. Skinner. 2001. Large Sample Evidence on the Debt Covenant Hypothesis. Working Paper, University of Michigan.

Elliott, J. A. and J. D. Hanna. 1996. Repeated Accounting Write-Offs and the Information Content of Earnings. Journal of Accounting Research 34: 135-155.

Forbes. 2002. The Corporate Scandal Sheet. http://www.forbes.com/home/2002/07/25/accountingtracker.html.

Guay, W. R., S.P. Kothari, and R. L. Watts. 1996. A Market Based Evaluations of Discretionary Accrual Models. Journal of Accounting Research 34: 83-105.

Guenther, D. A., and D. Young. 2000. The Association between Financial Accounting Measures and Real Economic Activity: A Multinational Study. Journal of Accounting and Economics 29: 53-72.

Gul, F. A., and L. K. Wah. 2002. Insider Entrenchment, Board Leadership Structure and Informativeness of Earnings. Working Paper, City University of Hong Kong.

Healy, P. M., and K. Palepu. 1990. Effectiveness of Accounting-based Dividend Covenants. Journal of Accounting and Economics 12: 97-124.

Healy, P. M., and J. M. Wahlen. 1999. A Review of the Earnings Management Literature and its Implications for Standard Setting. Accounting Horizons 13: 365-383.

Jain, P. K., J. Kim, and Z. Rezaee. 2003. Have the Sarbanes-Oxley Act of 2002 and the CEO Certifications made the Market Participants more Informed? Working Paper, University of Memphis.

Jain, P. K., and Z. Rezaee. 2003. An Examination of Value Relevance of the SarbanesOxley Act of 2002. Working Paper, University of Memphis.

Jones, J. 1991. Earnings Management during Import Relief Investigations. Journal of Accounting Research 29: 193-228.

Kasznik, R. 1999. On the Association between Voluntary Disclosure and Earnings Management. Journal of Accounting Research 33: 353-367.

Kothari, S.P., and R. G. Sloan. 1992. Information in Prices about Future Earnings: Implications for Earnings Response Coefficients, Journal of Accounting and Economics 15: 143-171. 
Kothari, S.P., A.J. Leone, and C. Wasley. 2004. R Performance Matched Discretionary Accrual Measures, working paper, Massachusetts Institute of Technology.

Larcker, D. F., and S. A. Richardson. 2003. Corporate Governance, Fees for Non-Audit Services and Accrual Choices. Working Paper, University of Pennsylvania.

Leuz, C., D. Nanda, and P. D. Wysocki. 2003. Earnings Management and Investor Protection: An International Comparison. Journal of Financial Economics 69: 505527.

Li, H., M. Pincus, and S. Rego. 2003. Market Reaction to Events Surrounding the Sarbanes-Oxley Act of 2002: Overall and as a Function of Earnings Management and Audit Committee Effectiveness. Working Paper, University of Iowa.

Lobo, G. and J. Zhou. 2005. Did Conservatism in Financial Reporting Increase after the Sarbanes-Oxley Act and CEO/CFO Certification of Financial Statements? Working Paper, University of Houston and SUNY-Binghamton.

Lopez, T. J., and L. L. Rees. 2001. The Effect of Meeting Analyst Forecasts and Systematic Positive Forecast Errors on the Information Content of Unexpected Earnings. Working Paper, Georgia State University.

Matsumoto, D. 2002. Management Incentives to Avoid Negative Earnings Surprises. The Accounting Review 77: 483 - 514.

McNichols, M. F. 2000. Research Design Issues in Earnings Management Studies. Journal of Accounting and Public Policy 19: 313-345.

McNichols, M. F. 2002. Discussion of the Quality of Accruals and Earnings: The Role of Accrual Estimation Errors. The Accounting Review 77 (Supplement): 61-69.

Subramanyam, K. R., and J. Wild. 1996. Going-concern Status, Earnings Persistence, and Informativeness of Earnings. Contemporary Accounting Research 13: 251-273.

Warfield, T., J. Wild, and K. Wild. 1995. Managerial Ownership, Accounting Choices and Informativeness of Earnings. Journal of Accounting and Economics 20: 61-91.

Watts, R., and J. Zimmerman. 1986. Positive Accounting Theory. Prentice-Hall, Englewood Cliffs, NJ.

Yeo, G.H.H., P.M. S. Tan, K. W. Ho and S. Chen. 2002. Corporate Ownership Structure and the Informativeness of Earnings. Journal of Business, Finance \& Accounting 29: 1023-1046. 
FIGURE 1: TIMELINE OF THE MAJOR SCANDALS IN 2001-2002

\begin{tabular}{|c|c|c|c|c|}
\hline Date & $\begin{array}{l}\text { October } \\
2001\end{array}$ & $\begin{array}{l}\text { November } \\
2001\end{array}$ & $\begin{array}{l}\text { January } \\
2002\end{array}$ & $\begin{array}{l}\text { February } \\
2002\end{array}$ \\
\hline & 1 & 1 & 1 & 1 \\
\hline$\frac{\text { candals that }}{\text { ent public }}$ & Enron & $\begin{array}{l}\text { Arthur } \\
\text { Andersen }\end{array}$ & $\begin{array}{l}\text { Kmart; } \\
\text { Homestore.com }\end{array}$ & $\begin{array}{l}\text { Global } \\
\text { Crossing; } \\
\text { Qwest }\end{array}$ \\
\hline
\end{tabular}

$\begin{array}{llllll} & \text { March } & \text { April } & \text { May } & \text { June } & \text { July } \\ \text { Date } & 2002 & 2002 & 2002 & 2002 & 2002\end{array}$

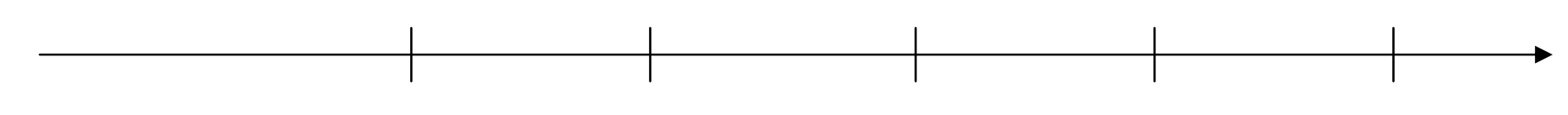

Scandals that

Xerox

AOL Time

Warner;

Bristol-Myers

WorldCom

Adelphia

CMS

went public

Squibb;

Energy;

Dynergy;

Duke Energy;

El Paso;

Merck;

Mirant;

Nicor Energy

Halliburton;

Peregrine

LLC

Systems;

Reliant

Energy;

Tyco 
FIGURE 2: TIME PERIODS ANALYSED

Quarter 1, 1987

Quarter 2, 2001

Quarter 3, 2002

Quarter 4, 2003

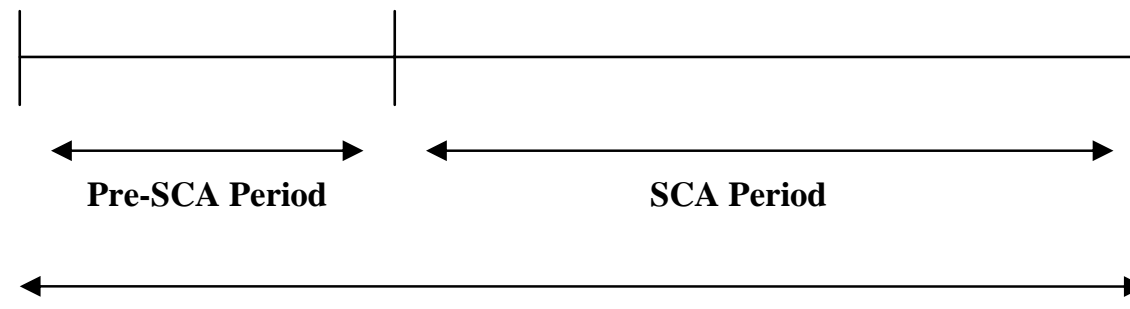

Pre-SOX Period

Post-SOX Period 


\section{Figure 3: Trends In Earnings Management 1987-2003}

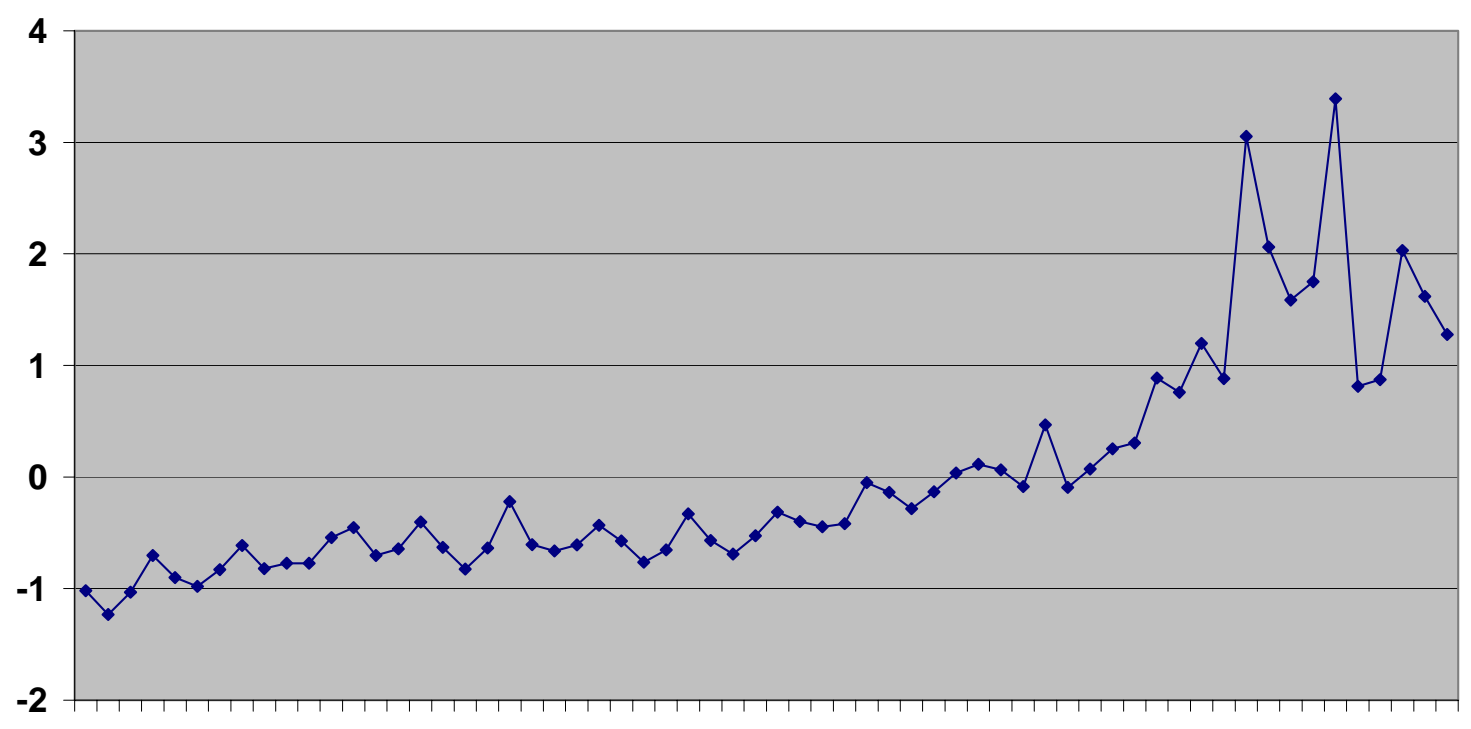

1988198919901991199219931994199519961997199819992000200120022003

Legend Figure 3: This figure plots EM_SCORE, our metric for earnings management over the 1987-2003 sample period. EM_SCORE is obtained by performing a principal factor analysis of the different earnings management metrics, including three measures of discretionary accruals (the absolute value of discretionary accruals estimated using the modified Jones, the modified Jones model controlling for performance, and the modified Jones model controlling for both performance and growth, respectively); the ratio of the absolute values of total accruals and cash flow from operations; the ratio of the change in accounts receivables to the change in sales; the ratio of the change in inventory to the change in sales; and the frequency of negative special items. 


\section{Figure 4: Trends in Earnings Informativeness 1987-2002}

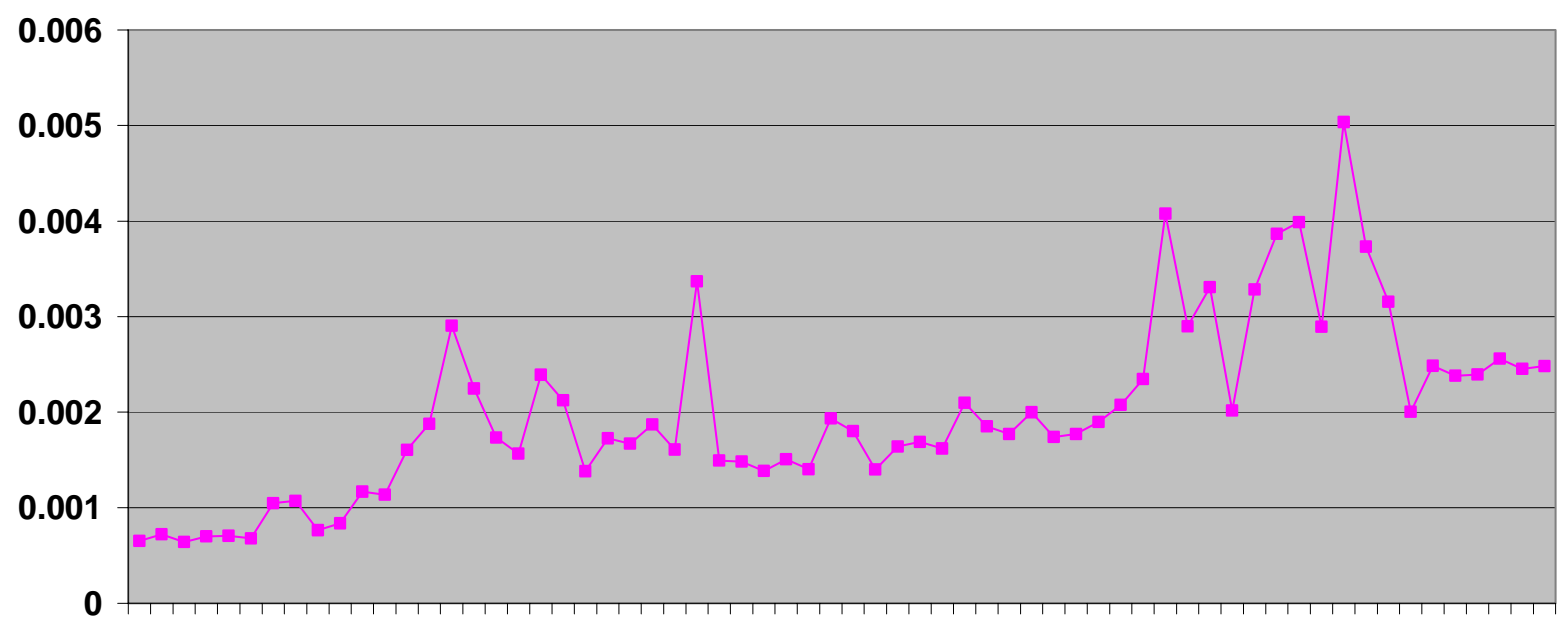

1987198819891990199119921993199419951996199719981999200020012002

Legend Figure 4: This figure plots the average firm-specific variance of the abnormal returns over the three-day earnings announcement window (days $-1,0$, and +1 ).

\section{Figure 5: Trends In Incentive Compensation 1992-2003}

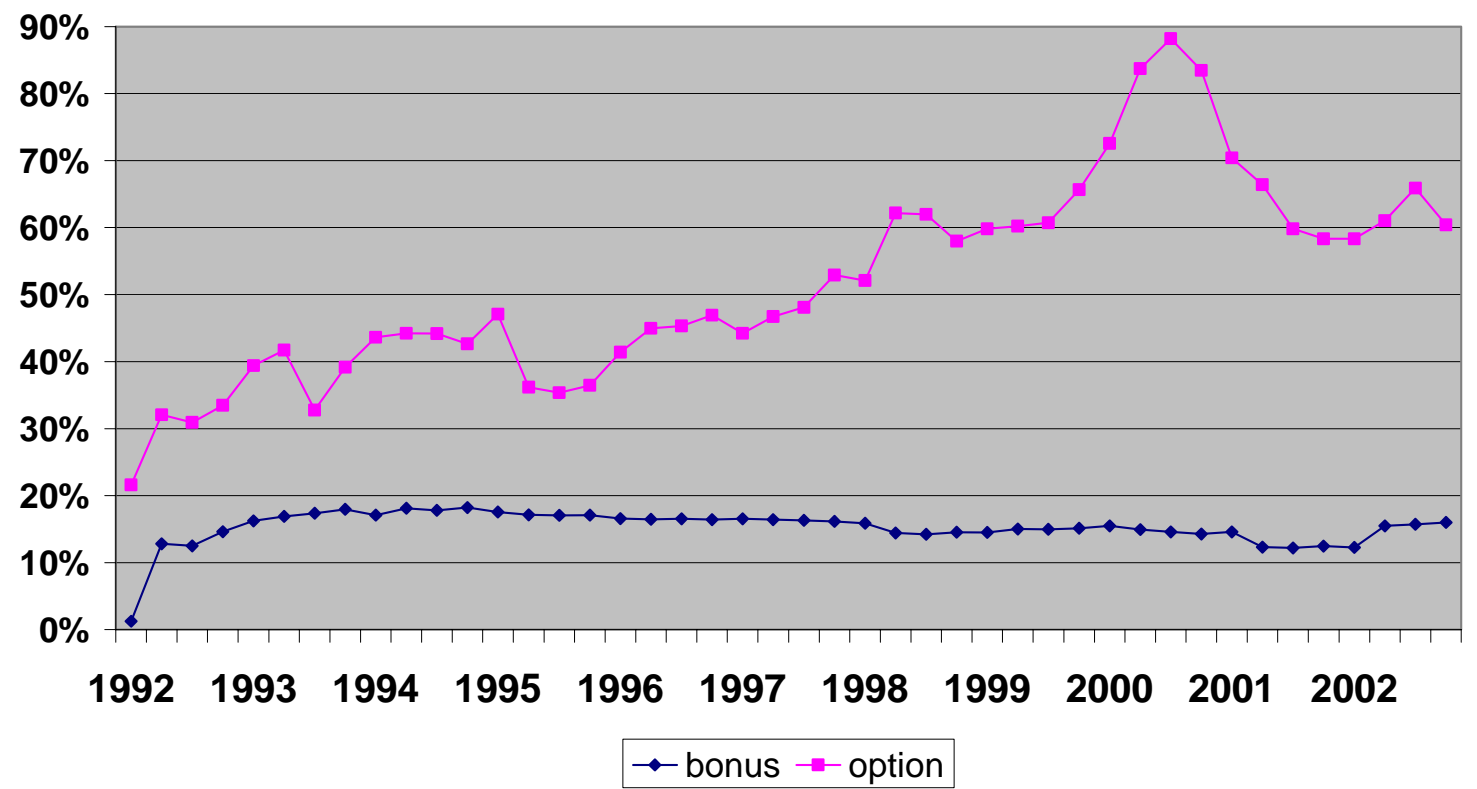

Legend Figure 5: This figure plots the average he average bonus compensation as a proportion of total compensation received by the top five executives of our sample firms and the average Black-Scholes value of option compensation as a proportion of total compensation received by the top five executives of our sample firms. 


\begin{tabular}{|c|c|c|c|c|c|}
\hline \multicolumn{6}{|c|}{$\begin{array}{c}\text { Table 1A: Full Sample } \\
\text { 1987-2002 } ; \mathrm{N}=81,061\end{array}$} \\
\hline & $\begin{array}{c}25^{\text {th }} \\
\text { Percentile }\end{array}$ & Mean & Median & $\begin{array}{c}75^{\text {th }} \\
\text { Percentile }\end{array}$ & $\begin{array}{c}\text { Standard } \\
\text { Deviation }\end{array}$ \\
\hline Total Assets & 71.261 & $2,706.541$ & 239.162 & 1015.811 & $16,505.351$ \\
\hline $\begin{array}{l}\text { Market } \\
\text { Capitalization }\end{array}$ & 55.861 & $2,478.202$ & 214.191 & 954.572 & $13,009.873$ \\
\hline Sales & 16.044 & 442.772 & 55.351 & 223.000 & $1,714.361$ \\
\hline Growth of Sales & -0.0505 & 0.002 & & 0.103 & 0.398 \\
\hline Total Accruals & -0.033 & -0.014 & & 0.006 & 0.046 \\
\hline cruals & 0.008 & 0.029 & & 0.039 & 0.029 \\
\hline Lev & 0.358 & 0.553 & & 0.705 & 0.298 \\
\hline Mar & 1.177 & 3.575 & & 39 & 38.712 \\
\hline GD & 0.019 & 0.031 & & 0.047 & 0.022 \\
\hline INl & -0.002 & 0.002 & 0 & 0.010 & .013 \\
\hline \multicolumn{6}{|c|}{$\begin{array}{l}\text { Table 1B: ExecuComp Sample } \\
\text { 1987-2003; } N=33,581\end{array}$} \\
\hline & $\begin{array}{c}25^{\text {th }} \\
\text { Percentile }\end{array}$ & Mean & Median & $\begin{array}{c}75^{\text {th }} \\
\text { Percentile }\end{array}$ & $\begin{array}{c}\text { Standard } \\
\text { Deviation }\end{array}$ \\
\hline Total Assets & 300.66 & $5,090.60$ & 767.451 & $2,445.58$ & $25,266.34$ \\
\hline $\begin{array}{l}\text { Market } \\
\text { Capitalization }\end{array}$ & 357.72 & 5,304.82 & 890.88 & 2,769.94 & 20,859.95 \\
\hline Sales & 80.89 & 875.792 & 207.675 & 631.50 & 2469.26 \\
\hline Growth of Sales & -0.038 & 0.007 & 0.031 & 0.098 & 0.335 \\
\hline Total Accruals & -0.030 & -0.013 & -0. & 0.004 & 0.041 \\
\hline Absolute Accru & 0.008 & 0.028 & 0 & 0.038 & 0.028 \\
\hline Leverage & 0.375 & 0.541 & 0.5 & 0.680 & 0.255 \\
\hline Market to Book & 1.618 & 4.430 & 2.501 & 4.090 & 48.007 \\
\hline BONUS & 0.044 & 0.154 & 0.130 & 0.226 & 0.139 \\
\hline OPTION & 0.194 & 0.347 & 0.312 & 0.461 & 0.200 \\
\hline \multicolumn{6}{|c|}{$\begin{array}{l}\text { Market Capitalization is measured as the price per share (Data 14) times the number of shares outstanding } \\
\text { (Data 15). Total Accruals is the difference between operating cash flows (Data 108), adjusted for } \\
\text { extraordinary items and discontinued operations (Data 78) and income before extraordinary items (Data 8); } \\
\text { Leverage is total liabilities (Data 54) divided by assets (Data 44); Market to Book ratio is calculated as the } \\
\text { market capitalization at the end of the fiscal quarter (Data } 14 \text { times Data 15) divided by the book value of } \\
\text { common equity (Data } 60 \text { ). GDP is the percent change in the real gross domestic product from the previous } \\
\text { quarter; IND } I N A A \text { is the average ROA of the industry to which the firm belongs, excluding the ROA of the } \\
\text { firm; BONUS is the average bonus compensation as a proportion of total compensation received by the top } \\
\text { five executives of a firm; OPTION represents the Black-Scholes value of option compensation as a } \\
\text { proportion of total compensation received by the top five executives of a firm. }\end{array}$} \\
\hline
\end{tabular}




\section{Table 2}

Summary Statistics of Earnings Management and Informativeness Metrics over Time Q1, 1987 - Q4, 2003

\begin{tabular}{|c|c|c|c|c|c|c|c|}
\hline \multirow{2}{*}{$\begin{array}{l}\text { Dependent } \\
\text { Variables }\end{array}$} & \multicolumn{3}{|c|}{$\begin{array}{c}\text { Panel A } \\
D e p_{j q}=a+b \times \text { Time }+c \times S O X\end{array}$} & \multicolumn{4}{|c|}{$\begin{array}{c}\text { Panel B } \\
\text { Dep } p_{j q}=a+b \times \text { Time }+c \times S O X+d \times S C A\end{array}$} \\
\hline & $\hat{a}$ & $\hat{b}$ & $\hat{c}$ & $\hat{a}$ & $\hat{b}$ & $\hat{c}$ & $\hat{d}$ \\
\hline$\left|D A_{1}\right|$ & $\begin{array}{r}0.018 \\
(10.32) \\
\end{array}$ & $\begin{array}{r}0.002 \\
(12.07) \\
\end{array}$ & $\begin{array}{r}-0.001 \\
(-0.24) \\
\end{array}$ & $\begin{array}{c}0.021 \\
(14.57)\end{array}$ & $\begin{array}{r}0.002 \\
(10.51)\end{array}$ & $\begin{array}{l}-0.012 \\
(-3.58)\end{array}$ & $\begin{array}{l}0.017 \\
(6.30)\end{array}$ \\
\hline$\left|D A_{2}\right|$ & $\begin{array}{c}0.019 \\
(11.02)\end{array}$ & $\begin{array}{r}0.002 \\
(11.45)\end{array}$ & $\begin{array}{l}-0.000 \\
(-0.02)\end{array}$ & $\begin{array}{c}0.022 \\
(15.87)\end{array}$ & $\begin{array}{r}0.002 \\
(9.94)\end{array}$ & $\begin{array}{l}-0.012 \\
(-3.54)\end{array}$ & $\begin{array}{l}0.017 \\
(6.68)\end{array}$ \\
\hline$\left|D A_{3}\right|$ & $\begin{array}{l}0.028 \\
(8.67) \\
\end{array}$ & $\begin{array}{r}0.003 \\
(7.22) \\
\end{array}$ & $\begin{array}{l}-0.007 \\
(-0.98)\end{array}$ & $\begin{array}{c}0.034 \\
(15.65)\end{array}$ & $\begin{array}{r}0.001 \\
(5.33) \\
\end{array}$ & $\begin{array}{l}-0.031 \\
(-6.14) \\
\end{array}$ & $\begin{array}{l}0.037 \\
(9.20) \\
\end{array}$ \\
\hline$|T A| /|C F O|$ & $\begin{array}{c}0.811 \\
(11.81)\end{array}$ & $\begin{array}{l}-0.005 \\
(-0.65)\end{array}$ & $\begin{array}{r}0.130 \\
(0.92)\end{array}$ & $\begin{array}{c}0.700 \\
(12.68)\end{array}$ & $\begin{array}{r}0.017 \\
(2.45)\end{array}$ & $\begin{array}{r}0.571 \\
(4.47)\end{array}$ & $\begin{array}{l}-0.666 \\
(-6.54)\end{array}$ \\
\hline$\triangle A R / \triangle S A L E S$ & $\begin{array}{l}0.093 \\
(2.45)\end{array}$ & $\begin{array}{r}-0.000 \\
(-0.07)\end{array}$ & $\begin{array}{r}-0.033 \\
(-0.23)\end{array}$ & $\begin{array}{l}0.082 \\
(2.05)\end{array}$ & $\begin{array}{r}0.002 \\
(0.41)\end{array}$ & $\begin{array}{r}0.017 \\
(0.11)\end{array}$ & $\begin{array}{l}-0.074 \\
(-0.96)\end{array}$ \\
\hline$\triangle I N V / \triangle S A L E S$ & $\begin{array}{c}0.396 \\
(60.73) \\
\end{array}$ & $\begin{array}{r}-0.008 \\
(-11.32) \\
\end{array}$ & $\begin{array}{r}0.038 \\
(1.49) \\
\end{array}$ & $\begin{array}{c}0.400 \\
(60.32) \\
\end{array}$ & $\begin{array}{r}-0.009 \\
(-11.21) \\
\end{array}$ & $\begin{array}{r}0.019 \\
(0.74) \\
\end{array}$ & $\begin{array}{l}0.027 \\
(2.09) \\
\end{array}$ \\
\hline $\begin{array}{l}\text { Negative Write- } \\
\text { Off }\end{array}$ & $\begin{array}{l}0.023 \\
(4.04)\end{array}$ & $\begin{array}{r}0.007 \\
(10.57)\end{array}$ & $\begin{array}{r}0.003 \\
(0.23)\end{array}$ & $\begin{array}{l}0.030 \\
(5.88)\end{array}$ & $\begin{array}{l}0.005 \\
(8.46)\end{array}$ & $\begin{array}{l}-0.026 \\
(-2.21)\end{array}$ & $\begin{array}{l}0.044 \\
(4.62)\end{array}$ \\
\hline$E M_{-} S C O R E_{j q}$ & $\begin{array}{l}-1.503 \\
(-9.96)\end{array}$ & $\begin{array}{r}0.190 \\
(10.75)\end{array}$ & $\begin{array}{l}-0.243 \\
(-0.76)\end{array}$ & $\begin{array}{l}-1.253 \\
(-11.91)\end{array}$ & $\begin{array}{r}0.132 \\
(10.12)\end{array}$ & $\begin{array}{l}-1.423 \\
(-5.84)\end{array}$ & $\begin{array}{l}1.784 \\
(9.19)\end{array}$ \\
\hline$A N N V A R_{j q}$ & $\begin{array}{l}0.001 \\
(4.58) \\
\end{array}$ & $\begin{array}{r}0.000 \\
(6.60)\end{array}$ & $\begin{array}{r}-0.001 \\
(-0.81)\end{array}$ & $\begin{array}{l}0.001 \\
(3.91)\end{array}$ & $\begin{array}{r}0.000 \\
(6.60) \\
\end{array}$ & $\begin{array}{l}-0.000 \\
(-0.25)\end{array}$ & $\begin{array}{l}-0.001 \\
(-1.58)\end{array}$ \\
\hline
\end{tabular}

SOX is a dummy variable taking a value of 1.0 in the period from Q3, 2002 through Q4, 2003; SCA is a dummy variable taking a value of 1.0 in the period from Q3, 2001 through Q2, 2002; $\left|D A_{j}\right| ; \mathrm{j}=1,2,3$ is defined as the absolute value of discretionary accruals estimated using the modified Jones, the modified Jones model controlling for performance, and the modified Jones model controlling for both performance and growth, respectively; $|T A| /|C F O|$ is the ratio of the absolute values of total accruals and cash flow from operations; $\triangle A R / \triangle S A L E S$ is the ratio of the change in accounts receivables to the change in sales; $\triangle I N V / \triangle S A L E S$, is the ratio of the change in inventory to the change in sales; Negative Write-Offs represent the frequency of negative special items; $E M \_S C O R E_{j q}$ is the score obtained by performing a principal factor analysis of the different earnings management metrics; $A N N V A R_{j q}$ is the variance of the abnormal returns over the three-day earnings announcement window (days $-1,0$, and +1 ) for firm $j$ in quarter $q$. 


\begin{tabular}{|c|c|c|c|c|c|c|}
\hline \multicolumn{7}{|c|}{ 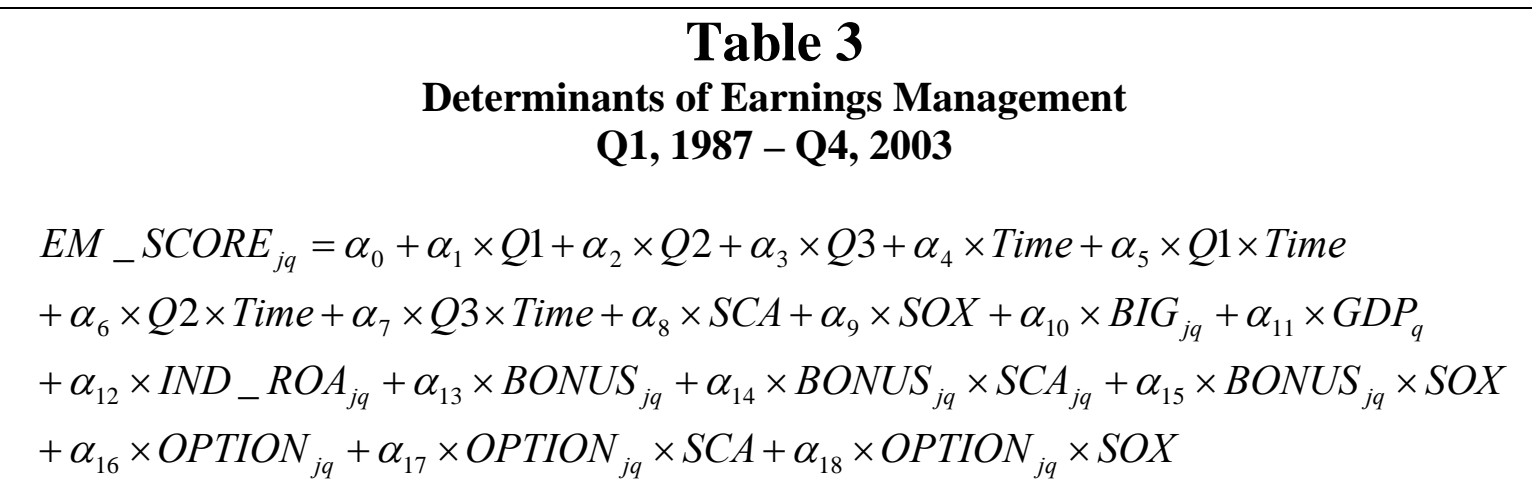 } \\
\hline & \multicolumn{2}{|c|}{ Panel A } & \multicolumn{2}{|c|}{ Panel B } & \multicolumn{2}{|c|}{ Panel C } \\
\hline & \multicolumn{2}{|c|}{$\begin{array}{c}\text { Full Sample } \\
N=80,963\end{array}$} & \multicolumn{4}{|c|}{$\begin{array}{c}\text { ExecuComp Sample } \\
\quad \mathrm{N}=33,595\end{array}$} \\
\hline & Coef. & t-stat. & Coef. & t-stat. & Coef. & t-stat. \\
\hline Intercept & 0.281 & 13.69 & -0.029 & -0.64 & -0.114 & -2.44 \\
\hline$Q 1$ & -0.368 & -15.70 & -0.207 & -4.07 & -0.197 & -3.89 \\
\hline$Q 2$ & -0.315 & -13.23 & -0.230 & -4.48 & -0.223 & -4.35 \\
\hline$Q 3$ & -0.297 & -12.54 & -0.202 & -3.89 & -0.194 & -3.76 \\
\hline Time & 0.019 & 11.40 & 0.035 & 10.58 & 0.031 & 9.32 \\
\hline Q1×Time & -0.013 & -5.83 & -0.026 & -5.63 & -0.027 & -5.89 \\
\hline Q2×Time & -0.007 & -2.85 & -0.014 & -3.06 & -0.015 & -3.25 \\
\hline Q3×Time & -0.007 & -2.93 & -0.015 & -3.29 & -0.016 & -3.47 \\
\hline$S C A$ & -0.037 & -2.87 & -0.055 & -3.18 & -0.126 & -3.09 \\
\hline SOX & -0.126 & -2.42 & -0.087 & -3.16 & -0.128 & -1.70 \\
\hline$B I G$ & -0.211 & -17.24 & -0.074 & -2.76 & -0.076 & -2.83 \\
\hline$G D P$ & -0.002 & -1.40 & -0.015 & -6.81 & -0.015 & -6.89 \\
\hline$I N D \_R O A$ & -17.867 & -69.30 & -20.590 & -57.98 & -20.205 & -56.52 \\
\hline$B O N U S \times 10^{3}$ & & & & & -0.196 & -0.00 \\
\hline$B O N U S \times S C A$ & & & & & 0.677 & 4.94 \\
\hline BONUS $\times$ SOX & & & & & -0.686 & -2.83 \\
\hline$O P T I O N \times 10^{3}$ & & & & & 0.378 & 14.98 \\
\hline$O P T I O N \times S C A \times 10^{3}$ & & & & & 0.004 & -0.05 \\
\hline$O P T I O N \times S O X \times 10^{3}$ & & & & & -0.342 & -2.39 \\
\hline $\mathrm{R}^{2} / \mathrm{F}$ & 0.136 & 1066.97 & 0.179 & 611.63 & 0.186 & 427.42 \\
\hline \multicolumn{7}{|c|}{$\begin{array}{l}E M_{-} S C O R E_{j q} \text { is the score obtained by principal component factor analysis on a firm-quarter basis using } \\
\left|D A_{1}\right|,|D A 2|,|D A 3|,|T A| / C F O \mid, \triangle A R / \triangle S A L E S, \triangle I N V / \triangle S A L E S \text {, and Negative Write-Off; } Q 1, Q 2 \text {, and } Q 3 \\
\text { are quarter dummies; Time is defined as the calendar year minus } 1987 ; S C A \text { is a dummy variable taking a } \\
\text { value of } 1.0 \text { in the period from Q3, } 2001 \text { through Q2, } 2002 \text { (SCA period), zero otherwise; } S O X \text { is a dummy } \\
\text { variable equal to } 1.0 \text { for all fiscal quarters ending after Q3, } 2002 \text { (post-SOX Period), zero otherwise; } B I G \text { is } \\
\text { a dummy variable equal to } 1.0 \text { if the auditor is a big-eight audit (or their successors) firm; GDP is the } \\
\text { percent change in the real gross domestic product from the previous quarter; IND } R O A \text { is the average ROA } \\
\text { of the industry to which firm } j \text { belongs, excluding the ROA of firm } j ; B O N U S \text { is the average bonus } \\
\text { compensation as a proportion of total compensation received by the top five executives of firm } j \text {; OPTION } \\
\text { represents the Black-Scholes value of option compensation as a proportion of total compensation received } \\
\text { by the top five executives of firm } j \text {. }\end{array}$} \\
\hline
\end{tabular}




\begin{tabular}{|c|c|c|c|c|}
\hline $\begin{array}{r}\text { Deter } \\
D E P_{j q}=\alpha_{0}+\alpha_{1} \times V A R_{-} Q T R+\alpha_{2} \times \\
+\alpha_{8} \times Q 3 \times T i m e+\alpha_{9} \times S C A+\alpha_{10} \times \\
+\alpha_{14} \times E M_{-} S C O R E_{j q}+\alpha_{15} \times E M\end{array}$ & $\begin{array}{r}\text { T } \\
\text { ants of } \mathbf{E} \\
1987-\mathbf{C} \\
+\alpha_{3} \times Q 2 \\
+\alpha_{11} \times S \\
O R E_{j q} \times\end{array}$ & $\begin{array}{l}\mathbf{4} \\
2 \mathbf{I n f o r n} \\
\mathbf{N}=\mathbf{8 0} \\
Q 3+\alpha_{5} \\
I S E_{j q}+\alpha \\
I S E_{j q}\end{array}$ & $\begin{array}{l}Q 1 \times \text { Tin } \\
13 \times I N D\end{array}$ & $\times Q 2 \times$ Time \\
\hline & & Depend & $\left(D E P_{j q}\right.$ & \\
\hline & & & & \\
\hline & & $\overline{4 R_{j q}}$ & & \\
\hline & Coef. & t-stat & Coef. & t-stat \\
\hline Intercept $\times 10^{3}$ & 0.551 & 2.93 & 6.960 & 4.05 \\
\hline$V A R \_Q T R$ & 0.526 & 81.92 & NA & NA \\
\hline$Q 1 \times 10^{2}$ & -0.024 & -0.87 & -0.817 & -3.29 \\
\hline$Q^{2} \times 10^{2}$ & 0.054 & 1.96 & -0.364 & -1.45 \\
\hline$Q 3 \times 10^{2}$ & -0.001 & -0.04 & -1.026 & -4.10 \\
\hline Time $\times 10^{4}$ & 0.673 & 3.83 & -2.002 & -1.25 \\
\hline$Q 1 \times$ Time $\times 10^{4}$ & 0.519 & 1.96 & 11.300 & 4.65 \\
\hline$Q 2 \times$ Time $\times 10^{4}$ & -0.533 & -1.93 & 1.459 & 0.58 \\
\hline$Q 3 \times$ Time $\times 10^{4}$ & 0.346 & 1.25 & 7.278 & 2.86 \\
\hline$S C A \times 10^{2}$ & -0.069 & -4.60 & -0.126 & -0.91 \\
\hline$S O X \times 10^{2}$ & 0.108 & 1.80 & 0.563 & 1.22 \\
\hline$S U R P R I S E_{j q} \times 10^{2}$ & 1.504 & 13.45 & 11.915 & 27.36 \\
\hline$G D P \times 10^{3}$ & -0.035 & -2.07 & 0.103 & 0.66 \\
\hline$I N D \_R O A \times 10^{6}$ & 0.164 & 0.01 & 0.595 & 0.00 \\
\hline$E M \_S C O R E_{j q} \times 10^{3}$ & 0.274 & 6.66 & 0.778 & 2.13 \\
\hline$E M \_S C O R E_{j q} \times S U R P R I S E_{j q} \times 10^{3}$ & -1.970 & -2.74 & -5.040 & -1.77 \\
\hline $\mathrm{R}^{2} / \mathrm{F}$ & 0.089 & 565.81 & 0.011 & 68.11 \\
\hline $\begin{array}{l}A N N V A R_{j q} \text { is the variance of the abnormal } \\
\text { firm } j \text { in quarter } q \text {; } A N N R E T_{j q} \text { is the sum } \\
\text { firm and each quarter; } V A R \_Q T R \text { is the va } \\
Q 1, Q 2 \text {, and } Q 3 \text { are quarter dummies; Tim } \\
\text { value of } 1.0 \text { in the period from Q3, } 2001 \text { th } \\
1.0 \text { for all fiscal quarters ending after } \mathrm{Q} 3,2 \\
\text { announcement for firm } j \text { in quarter } q \text { defir } \\
\text { measured as the earnings per share for the } \\
\text { year scaled by price, and for the regressi } \\
\text { surprise metric described the preceding se } \\
\text { previous quarter; IND_ROA is the averag } \\
E M \_S C O R E_{j q} \text { is the score obtained by prin } \\
\triangle A R / \triangle S A L E S, \triangle I N V / \triangle S A L E S \text {, and Negativ }\end{array}$ & $\begin{array}{l}\text { ns over the } \\
\text { normal ret } \\
\text { ce of return } \\
\text { defined as } \\
\text { Qh } 2 \text {, } 2002 \\
\text { (post-SOX } \\
\text { as follows: } \\
\text { rrter less th } \\
\text { vith the de } \\
\text { ce; GDP is } \\
\text { A of the in } \\
\text { factor anal } \\
\text { ite-Off. }\end{array}$ & $\begin{array}{l}\text { ay earnings } \\
\text { er the thre } \\
\text { is other tha } \\
\text { hdar year } \mathrm{r} \\
\text { period), ze } \\
\text { zero other } \\
\text { regression } \\
\text { gs per sha } \\
\text { variable } A \\
\text { rcent chan } \\
\text { o which th } \\
\text { a firm-qua }\end{array}$ & $\begin{array}{l}\text { window } \\
\text { announce } \\
\text { earnings } \\
C A \text { is a du } \\
O X \text { is a du } \\
S E_{j q} \text { is the } \\
q \text { as the d } \\
\text { sponding } \\
\text { measure } \\
\text { ross dom } \\
\text { excluding } \\
\left|D A_{1}\right|, \mid D A\end{array}$ & $\begin{array}{l}\text { 1, } 0 \text {, and }+1 \text { ) for } \\
\text { indow for each } \\
\text { cement period.; } \\
\text { ariable taking a } \\
\text { ariable equal to } \\
\text { in the earnings } \\
\text { nt variable it is } \\
\text { in the previous } \\
\text { e square of the } \\
\text { oduct from the } \\
\text { OA of the firm; } \\
13|,| T A|/ C F O| \text {, }\end{array}$ \\
\hline
\end{tabular}

